\title{
Peroxisome proliferator-activated receptor delta +294T > C polymorphism and serum lipid levels in the Guangxi Bai Ku Yao and Han populations
}

\author{
Lin Miao ${ }^{1}$, Rui-Xing Yin ${ }^{*}$, Dong-Feng Wu', Xiao-Li Cao ${ }^{1}$, Qing Li ${ }^{1}$, Xi-Jiang Hu${ }^{1}$, Ting-Ting Yan',
} Lynn Htet Htet Aung ${ }^{1}$, De-Zhai Yang ${ }^{2}$, Wei-Xiong Lin²

\begin{abstract}
Background: The association of peroxisome proliferator-activated receptor delta (PPARD) +294T > C polymorphism and serum lipid levels is inconsistent in several previous studies. Bai Ku Yao is an isolated subgroup of the Yao minority in China. The present study was undertaken to detect the association of PPARD +294T > C (rs2016520) polymorphism and several environmental factors with serum lipid levels in the Guangxi Bai Ku Yao and Han populations.
\end{abstract}

Methods: A total of 609 subjects of Bai Ku Yao and 573 participants of Han Chinese were randomly selected from our previous stratified randomized cluster samples. Genotyping of the PPARD +294T > C polymorphism was performed by polymerase chain reaction and restriction fragment length polymorphism combined with gel electrophoresis, and then confirmed by direct sequencing.

Results: The levels of serum total cholesterol (TC), high-density lipoprotein cholesterol (HDL-C), apolipoprotein (Apo) Al and ApoB were lower in Bai Ku Yao than in Han ( $P<0.001$ for all). The frequency of $\mathrm{T}$ and $\mathrm{C}$ alleles was 77.50\% and 22.50\% in Bai Ku Yao, and $72.43 \%$ and $27.57 \%$ in Han $(P<0.01)$; respectively. The frequency of TT, TC and CC genotypes was 60.59\%, 33.83\% and 5.53\% in Bai Ku Yao, and 52.18\%, 40.50\% and $7.32 \%$ in Han $(P<0.05)$; respectively. The subjects with CC genotype in Bai Ku Yao had higher serum LDL-C and ApoB levels and lower the ratio of ApoAl to ApoB than the subjects with $\Pi$ and $T C$ genotypes in females but not in males. The $C$ allele carriers in Han had higher serum TC levels in males $(P<0.01)$ and ApoB levels in females $(P<0.05)$ than the $C$ allele noncarriers. Serum TC and ApoB levels were correlated with genotypes in Han $(P<0.05$ for each) but not in Bai Ku Yao. Serum lipid parameters were also correlated with sex, age, body mass index, alcohol consumption, cigarette smoking, and blood pressure in both ethnic groups.

Conclusions: These results suggest that the association of PPARD $+294 \mathrm{~T}>\mathrm{C}$ polymorphism and serum lipid levels is different between the Bai Ku Yao and Han populations. The discrepancy between the two ethnic groups might partly result from different PPARD $+294 \mathrm{~T}>\mathrm{C}$ polymorphism or PPARD gene-enviromental interactions.

\section{Introduction}

Elevated levels of total cholesterol (TC), triglyceride (TG), low-density lipoprotein cholesterol (LDL-C) and apolipoprotein (Apo) B, together with decreased levels of high-density lipoprotein cholesterol (HDL-C), and ApoAI, are associated with an increased risk of coronary

\footnotetext{
* Correspondence: yinruixing@yahoo.com.cn

'Department of Cardiology, Institute of Cardiovascular Diseases, the First Affiliated Hospital, Guangxi Medical University, 22 Shuangyong Road,

Nanning 530021, Guangxi, People's Republic of China

Full list of author information is available at the end of the article
}

artery disease (CAD) [1-4]. Genetic and environmental factors [4-10] and their interactions [11,12] are believed to regulate both metabolic and cellular function, and the serum lipid concentrations. Twin and family studies have shown the variable estimates of heritability for plasma lipid phenotypes ranging from 40 to $60 \%$ in different studies supporting the idea of a strong genetic component in the development of dyslipidemia [13-17].

Peroxisome proliferator-activated receptors (PPARs) are nuclear transcription factors involved in the 
regulation of lipid and glucose metabolism. The family includes PPAR-alpha (PPARA), PPAR-gamma (PPARG), and PPAR-delta (PPARD). PPARA is mainly expressed in liver, muscle, kidney and heart, PPARG is most abundant in adipocytes, intestinal cells and macrophages and PPARD is expressed in many tissues [18-20]. Each subgroup is activated by a certain variety of fatty acids and their derivatives and by specific pharmacological ligands. After forming obligate heterodimers with the retinoid $x$ receptor, PPARs bind to specific elements in the promoter region of target genes, thereby altering metabolism by activating a network of downstream genes [21,22]. PPARs are encoded by separate genes and characterized by distinct tissue and developmental distribution patterns. The PPARD gene, located on chromosome 6p21.2-p21.1, is involved in cellular transport, storage and metabolism of lipids [23], which ultimately translates into a metabolic response. This gene is equally actively expressed in both adipose tissue and skeletal muscles, primarily in slow twitch muscle fibers. Treatment of obese rhesus monkeys with the synthetic PPARD agonist GW501516 resulted in an increase of HDL-C levels and a decrease of plasma TG [24,25]. In addition, $\mathrm{db} / \mathrm{db}$ mice expressing an activated form of PPARD are resistant to obesity and hyperlipidemia when overfed and muscle-specific overexpression of the receptor increased the number of muscle fibers with high oxidative metabolic capability [26,27]. These results suggest that PPARD may play a role in the development of metabolic perturbations associated with dyslipidemia and predisposing to atherosclerosis. The $+294 \mathrm{~T}>\mathrm{C}$ (rs2016520) polymorphism in the 5'-untranslated region in exon 4 of the PPARD gene is located 87 nucleotides upstream of the start codon. It was shown that the single nucleotide polymorphism (SNP) influenced binding of Sp-1 resulting in higher transcriptional activity for the rare $\mathrm{C}$ allele than the common T allele [28]. Several previous studies have showed that the PPARD $+294 \mathrm{~T}>$ $C$ polymorphism was associated with modifications of serum lipid concentrations in healthy subjects and the risk of CAD [28-35] in dyslipidemic women and hypercholesterolemic men and cholesterol metabolites in Alzheimer's disease patients [36]. But the results are inconsistent in diverse populations [34,37].

There are 56 ethnic groups in China. Han is the largest ethnic group and Yao is the eleventh largest minority among the 55 minority groups according to the population size. Bai Ku Yao (White-trouser Yao), an isolated branch of the Yao minority, is named so because all of men wear white knee-length knickerbockers. The population size is about 30000 . Because of isolation from the other ethnic groups, the special customs and cultures including their clothing, intra-ethnic marriages, ballad, funeral, bronze drum, spinning top, dietary habits, and corn wine and rum intakes are still completely preserved to the present day. In previous epidemiological studies, we showed that several serum lipid parameters were lower in Bai Ku Yao than in Han Chinese from the same area [6,7]. These differences in serum lipid profiles are still not well known. We hypothesized that the genetic and environmental risk factors for dyslipidemia may be different between the two ethnic groups. Therefore, the aim of the present study was to detect the association of PPARD $+294 \mathrm{~T}>$ $\mathrm{C}$ polymorphism and several environmental factors with serum lipid parameters in the Guangxi Bai Ku Yao and Han populations.

\section{Materials and methods Study population}

A total of 609 participants of Bai Ku Yao who reside in Lihu and Baxu villages in Nandan County, Guangxi Zhuang Autonomous Region, People's Republic of China were randomly selected from our previous stratified randomized cluster samples [6,7]. The ages of the subjects ranged from 15 to 80 years, with an average age of 41.75 \pm 15.46 years. There were 288 males $(47.29 \%)$ and 321 females (52.71\%). All subjects were rural agricultural workers. The subjects accounted for $2.03 \%$ of total Bai $\mathrm{Ku}$ Yao population. During the same period, a total of 573 subjects of Han Chinese who reside in the same villages were also randomly selected from our previous stratified randomized cluster samples [6,7]. The average age of the subjects was $42.18 \pm 15.63$ years (range 15 to 80 ). There were 260 men (45.38\%) and 313 women (54.62\%). All of them were also rural agricultural workers. All study subjects were essentially healthy and had no evidence of any chronic illness, including hepatic, renal, or thyroid. The participants with a history of heart attack or myocardial infarction, stroke, congestive heart failure, diabetes or fasting blood glucose $\geq 7.0 \mathrm{mmol} / \mathrm{L}$ determined by glucose meter have been excluded. The participants were not taking medications known to affect serum lipid levels (lipid-lowering drugs such as statins or fibrates, beta-blockers, diuretics, or hormones). The present study was approved by the Ethics Committee of the First Affiliated Hospital, Guangxi Medical University. Informed consent was obtained from all subjects after they received a full explanation of the study.

\section{Epidemiological survey}

The survey was carried out using internationally standardized methods, following a common protocol [38]. Information on demographics, socioeconomic status, and lifestyle factors was collected with standardized questionnaires. The alcohol information included questions about the number of liangs (about $50 \mathrm{~g}$ ) of rice wine, corn wine, rum, beer, or liquor consumed during 
the preceding 12 months. Alcohol consumption was categorized into groups of grams of alcohol per day: < 25 and $\geq 25$. Smoking status was categorized into groups of cigarettes per day: $<20$ and $\geq 20$. At the physical examination, several anthropometric parameters, such as height, weight, and waist circumference were measured. Sitting blood pressure was measured three times with the use of a mercury sphygmomanometer after the subjects had a 5-minute rest, and the average of the three measurements was used for the level of blood pressure. Systolic blood pressure was determined by the first Korotkoff sound, and diastolic blood pressure by the fifth Korotkoff sound. Body weight, to the nearest 50 grams, was measured using a portable balance scale. Subjects were weighed without shoes and in a minimum of clothing. Height was measured, to the nearest $0.5 \mathrm{~cm}$, using a portable steel measuring device. From these two measurements body mass index (BMI, $\mathrm{kg} / \mathrm{m}^{2}$ ) was calculated.

\section{Biochemical analysis}

A venous blood sample of $8 \mathrm{~mL}$ was obtained from all subjects between 8 and $11 \mathrm{AM}$, after at least 12 hours of fasting, from a forearm vein after venous occlusion for few seconds in a sitting position. A part of the sample $(3 \mathrm{~mL})$ was collected into glass tubes and allowed to clot at room temperature, and used to determine serum lipid levels. Another part of the sample $(5 \mathrm{~mL})$ was transferred to tubes with anticoagulate solution $(4.80 \mathrm{~g} / \mathrm{L}$ citric acid, $14.70 \mathrm{~g} / \mathrm{L}$ glucose, and $13.20 \mathrm{~g} / \mathrm{L}$ tri-sodium citrate) and used to extract DNA. Immediately following clotting serum was separated by centrifugation for 15 minutes at $3000 \mathrm{rpm}$. The levels of TC, TG, HDL-C, and LDL-C in samples were determined by enzymatic methods with commercially available kits, Tcho-1, TG-LH (RANDOX Laboratories Ltd., Ardmore, Diamond Road, Crumlin Co. Antrim, United Kingdom, BT29 4QY), Cholestest N HDL, and Cholestest LDL (Daiichi Pure Chemicals Co., Ltd., Tokyo, Japan); respectively. Serum ApoAI and ApoB levels were detected by the immunoturbidimetric immunoassay using a commercial kit (RANDOX Laboratories Ltd.). All determinations were performed with an autoanalyzer (Type 7170A; Hitachi Ltd., Tokyo, Japan) in the Clinical Science Experiment Center of the First Affiliated Hospital, Guangxi Medical University [6,7].

\section{DNA amplification and genotyping}

Genomic DNA was isolated from peripheral blood leukocytes using the phenol-chloroform method [8-12]. The extracted DNA was stored at $4^{\circ} \mathrm{C}$ until analysis. Genotyping of the PPARD $+294 \mathrm{~T}>\mathrm{C}$ polymorphism was performed by polymerase chain reaction and restriction fragment length polymorphism (PCR-RFLP) [35,37]. PCR amplification was performed using 5'-CATGGTATAG
CACTGCAGGAA-3' and 5'-CTTCC TCCTGTGGCTGCTC-3' (Sangon, Shanghai, People's Republic of China) as the forward and reverse primer pairs; respectively. Each amplification reaction was performed using $100 \mathrm{ng}$ genomic DNA in $25 \mu \mathrm{L}$ of reaction mixture consisting of $1.0 \mu \mathrm{L}$ of each primer $(10 \mu \mathrm{mol} / \mathrm{L})$, $12.5 \mu \mathrm{L} 2 \times$ Taq PCR MasterMix (constituent: $0.1 \mathrm{U} \mathrm{Taq}$ polymerase $/ \mu \mathrm{L}, 500 \mu \mathrm{M}$ dNTP each and PCR buffer). After initial denaturizing at $95^{\circ} \mathrm{C}$ for $5 \mathrm{~min}$, the reaction mixture was subjected to 30 cycles of $45 \mathrm{~s}$ denaturation at $94^{\circ} \mathrm{C}, 45 \mathrm{~s}$ annealing at $62^{\circ} \mathrm{C}$ and extension $45 \mathrm{~s}$ at $72^{\circ}$ $\mathrm{C}$, followed by a final $8 \mathrm{~min}$ extension at $72^{\circ} \mathrm{C}$. After electrophoresis on a $2.0 \%$ agarose gel with $0.5 \mu \mathrm{g} / \mathrm{mL}$ ethidium bromide, the amplification products were visualized under ultraviolet light. Then $5 \mathrm{U}$ of $B s l \mathrm{I}$ restriction enzyme was added directly to the PCR products $(6 \mu \mathrm{L})$ and digested at $55^{\circ} \mathrm{C}$ overnight. After restriction enzyme digestion of the amplified DNA, the genotypes were identified by electrophoresis on $2.5 \%$ agarose gels and visualized with ethidium-bromide staining ultraviolet illumination. The genotypes were scored by an experienced reader blinded to epidemiological data and serum lipid levels. Six samples (TT, TC and CC genotypes in two; respectively) detected by the PCR-RFLP were also confirmed by direct sequencing. The PCR products were purified by low melting point gel electrophoresis and phenol extraction, and then the DNA sequences were analyzed in Shanghai Sangon Biological Engineering Technology \& Services Co., Ltd., People's Republic of China.

\section{Diagnostic criteria}

The normal values of serum TC, TG, HDL-C, LDL-C, ApoAI, ApoB levels, and the ratio of ApoAI to ApoB in our Clinical Science Experiment Center were 3.10-5.17, 0.56-1.70, 0.91-1.81, 2.70-3.20 mmol/L, 1.00-1.78, 0.63$1.14 \mathrm{~g} / \mathrm{L}$, and 1.00-2.50; respectively. The individuals with $\mathrm{TC}>5.17 \mathrm{mmol} / \mathrm{L}$ and/or TG $>1.70 \mathrm{mmol} / \mathrm{L}$ were defined as hyperlipidemic [6,7]. Hypertension was diagnosed according to the criteria of 1999 World Health Organization-International Society of Hypertension Guidelines for the management of hypertension $[39,40]$. The diagnostic criteria of overweight and obesity were according to the Cooperative Meta-analysis Group of China Obesity Task Force. Normal weight, overweight and obesity were defined as a BMI $<24,24-28$, and $>$ $28 \mathrm{~kg} / \mathrm{m}^{2}$; respectively [41].

\section{Statistical analyses}

Epidemiological data were recorded on a pre-designed form and managed with Excel software. All statistical analyses were done with the statistical software package SPSS 13.0 (SPSS Inc., Chicago, Illinois). Quantitative variables were expressed as mean \pm standard deviation 
(serum TG levels were presented as medians and interquartile ranges). Qualitative variables were expressed as percentages. Allele frequency was determined via direct counting, and the standard goodness-of-fit test was used to test the Hardy-Weinberg equilibrium. Difference in genotype distribution between the groups was obtained using the chi-square test. The difference in general characteristics between Bai Ku Yao and Han was tested by the Student's unpaired $t$-test. The association of genotypes and serum lipid parameters was tested by analysis of covariance (ANCOVA). Sex, age, BMI, blood pressure, alcohol consumption, cigarette smoking were adjusted for the statistical analysis. In order to evaluate the association of serum lipid levels with genotypes ( $\mathrm{TT}=1$, $\mathrm{TC}=2, \mathrm{CC}=3$ ) and several environment factors, multiple linear regression analysis with stepwise modeling was also performed in the combined population of Bai Ku Yao and Han, Bai Ku Yao, Han; respectively. A $P$ value of less than 0.05 was considered statistically significant.

\section{Results}

\section{General characteristics and serum lipid levels}

Table 1 gives the general characteristics and serum lipid levels between the Bai $\mathrm{Ku}$ Yao and Han populations. The levels of height, weight, BMI, serum TC, HDL-C, ApoAI and ApoB were lower in Bai Ku Yao than in Han Chinese $(P<0.05-0.001)$, whereas the ratio of ApoAI to ApoB was higher in Bai Ku Yao than in Han $(P<0.05)$. There were no significant differences in the levels of systolic blood pressure, diastolic blood pressure, pulse pressure, serum TG, LDL-C, age structure, the percentages of subjects who consumed alcohol or smoked cigarettes, or the ratio of male to female between the two ethnic groups $(P>0.05$ for all).

\section{Results of electrophoresis and genotyping}

After the genomic DNA of the samples was amplified by PCR and imaged by $2.0 \%$ agarose gel electrophoresis, the purpose gene of $269 \mathrm{bp}$ nucleotide sequences could be found in all samples (Figure 1). The genotypes identified were named according to the presence or absence of the enzyme restriction sites, when a $\mathrm{T}$ to $\mathrm{C}$ transversion at +294 locus of the PPARD gene. The presence of the cutting site indicates the $\mathrm{C}$ allele, while its absence indicates the $\mathrm{T}$ allele (cannot be cut). Thus, the TT genotype is homozygote for the absence of the site (band at $269 \mathrm{bp})$, TC genotype is heterozygote for the absence

Table 1 Comparison of demographic, lifestyle characteristics and serum lipid levels between Bai Ku Yao and Han Chinese

\begin{tabular}{|c|c|c|c|c|}
\hline Parameter & Bai Ku Yao & Han Chinese & $t(\chi)^{2}$ & $P$ \\
\hline Number & 609 & 573 & - & - \\
\hline Male/female & $288 / 321$ & $260 / 313$ & 0.436 & 0.509 \\
\hline Age (years) & $41.75 \pm 15.46$ & $42.18 \pm 15.63$ & -0.480 & 0.631 \\
\hline Height $(\mathrm{cm})$ & $152.56 \pm 7.40$ & $154.33 \pm 8.40$ & -3.828 & 0.000 \\
\hline Weight (kg) & $51.65 \pm 7.39$ & $53.62 \pm 8.92$ & -4.151 & 0.000 \\
\hline Body mass index $\left(\mathrm{kg} / \mathrm{m}^{2}\right)$ & $22.14 \pm 2.41$ & $22.48 \pm 3.03$ & -2.109 & 0.035 \\
\hline Systolic blood pressure (mmHg) & $119.71 \pm 17.96$ & $120.73 \pm 16.00$ & -1.036 & 0.300 \\
\hline Diastolic blood pressure $(\mathrm{mmHg})$ & $75.80 \pm 9.64$ & $75.97 \pm 10.40$ & -0.293 & 0.769 \\
\hline Pulse pressure $(\mathrm{mmHg})$ & $43.91 \pm 13.24$ & $44.76 \pm 11.00$ & -1.217 & 0.224 \\
\hline \multicolumn{5}{|l|}{ Cigarette smoking [n (\%)] } \\
\hline Nonsmoker & $423(69.5)$ & $404(70.5)$ & & \\
\hline$<20$ cigarettes/day & $82(13.4)$ & $72(12.6)$ & & \\
\hline$\geq 20$ cigarettes/day & $104(17.1)$ & $97(16.9)$ & 0.233 & 0.890 \\
\hline \multicolumn{5}{|l|}{ Alcohol consumption [n (\%)] } \\
\hline Nondrinker & $343(56.3)$ & $342(59.7)$ & & \\
\hline$<25 \mathrm{~g} /$ day & $163(26.8)$ & $149(26.0)$ & & \\
\hline$\geq 25 \mathrm{~g} /$ day & $103(16.9)$ & $82(14.3)$ & 1.919 & 0.383 \\
\hline Total cholesterol (mmol/L) & $4.35 \pm 0.92$ & $4.76 \pm 1.03$ & -7.215 & 0.000 \\
\hline Triglycerides (mmol/L) & $0.98(0.78)$ & $1.01(0.66)$ & -0.956 & 0.339 \\
\hline $\mathrm{HDL}-\mathrm{C}(\mathrm{mmol} / \mathrm{L})$ & $1.68 \pm 0.41$ & $1.92 \pm 0.49$ & -8.968 & 0.000 \\
\hline LDL-C (mmol/L) & $2.57 \pm 0.77$ & $2.61 \pm 0.76$ & -0.823 & 0.411 \\
\hline Apolipoprotein (Apo) Al (g/L) & $1.32 \pm 0.31$ & $1.41 \pm 0.24$ & -5.896 & 0.000 \\
\hline ApoB (g/L) & $0.83 \pm 0.23$ & $0.91 \pm 0.22$ & -5.771 & 0.000 \\
\hline ApoAl/ApoB & $1.71 \pm 0.72$ & $1.64 \pm 0.49$ & 1.998 & 0.046 \\
\hline
\end{tabular}

HDL-C, high-density lipoprotein cholesterol; LDL-C, low-density lipoprotein cholesterol. The value of TG was presented as median (interquartile range). The difference between the two ethnic groups was determined by the Wilcoxon-Mann-Whitney test. 


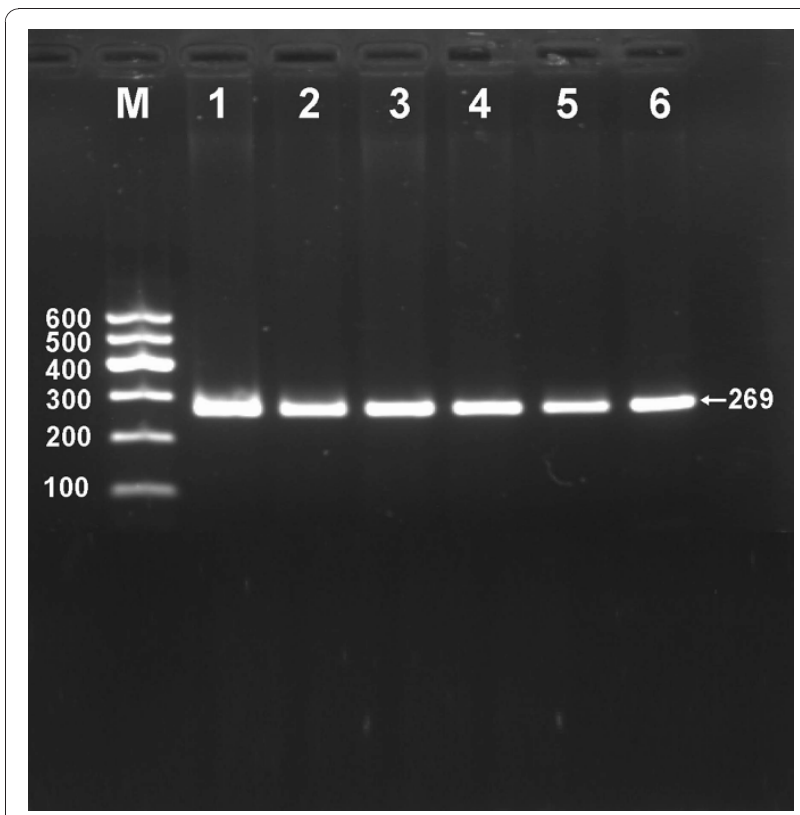

Figure 1 Electrophoresis of PCR products of the samples. Lane M, 100 bp marker ladder; lanes 1-6, samples. The 269 bp bands are the target genes.

and presence of the site (bands at 269-, 167- and 102-bp), and $\mathrm{CC}$ genotype is homozygote for the presence of the site (bands at 167- and 102- bp; Figure 2). The genotype distribution was consistent with the Hardy-Weinberg equilibrium.

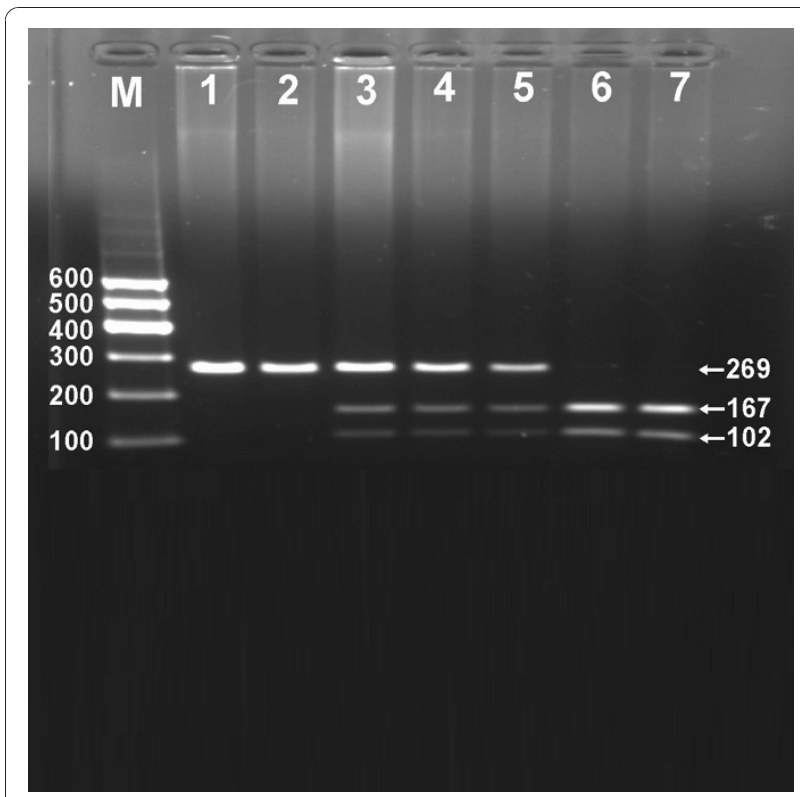

Figure 2 Genotyping of the PPARD +294T > C polymorphism. Lane M, 100 bp marker ladder; lanes 1 and 2, TT genotype (269 bp); lanes 3-5, TC genotype (269-, 167- and 102-bp); and lanes 6 and 7, CC genotype (167- and 102-bp).

\section{Genotypic and allelic frequencies}

The genotypic and allelic frequencies of PPARD $+294 \mathrm{~T}>\mathrm{C}$ polymorphism are shown in Table 2 . The frequency of $\mathrm{T}$ and $\mathrm{C}$ alleles was $77.50 \%$ and $22.50 \%$ in Bai $\mathrm{Ku}$ Yao, and $72.43 \%$ and $27.57 \%$ in Han $(P<0.01)$; respectively. The frequency of TT, TC and CC genotypes was $60.59 \%, 33.83 \%$ and $5.53 \%$ in Bai $\mathrm{Ku}$ Yao, and $52.18 \%, 40.50 \%$ and $7.32 \%$ in Han $(P<0.05)$; respectively. There was no significant difference in the genotypic and allelic frequencies between males and females in both ethnic groups.

\section{Results of sequencing}

The results were shown as TT, TC and CC genotypes by PCR-RFLP, the TT, TC and CC genotypes were also confirmed by sequencing (Figure 3); respectively.

\section{Genotypes and serum lipid levels}

As shown in Table 3, the levels of LDL-C, ApoB and the ratio of ApoAI to ApoB in Bai $\mathrm{Ku}$ Yao were significant difference among the three genotypes in females but not in males $(P<0.05$ for all $)$. The subjects with $\mathrm{CC}$ genotype had higher serum LDL-C and ApoB levels and lower the ratio of ApoAI to ApoB than the subjects with TT and TC genotypes in females.

The levels of TC and ApoB in the total Han population were significant difference among the three genotypes $(P<0.05$ for all). The $\mathrm{C}$ allele carriers (TC and $\mathrm{CC}$ genotypes) had higher serum TC and ApoB levels as compared with the $\mathrm{C}$ allele noncarriers (TT genotype). When serum lipid levels were analyzed according to sex, the difference in serum TC levels in Han Chinese was significant in males $(P<0.01)$ but not in females, whereas the difference in serum ApoB levels was significant in females $(P<0.05)$ but not in males.

There was no significant difference in the remaining serum lipid parameters among the three genotypes in Bai Ku Yao, Han, males, or females $(P>0.05$ for all); respectively.

\section{Relative factors for serum lipid parameters}

Multiple linear regression analysis showed that serum TC, TG and ApoB levels were correlated with genotypes in the combined population of Bai $\mathrm{Ku}$ Yao and Han $(P<0.05$ for all). Serum TC and ApoB levels were correlated with genotypes in $\operatorname{Han}(P<0.05$ for each) but not in Bai Ku Yao (Table 4). Serum lipid parameters were also correlated with sex, age, BMI, alcohol consumption, cigarette smoking, and blood pressure in both ethnic groups (Table 4).

\section{Discussion}

The present study showed that the levels of serum TC, HDL-C, ApoAI and ApoB were lower in Bai Ku Yao than in Han Chinese. There was no significant 
Table 2 Comparison of the genotype and allele frequencies of PPARD +294T > C polymorphism in Bai Ku Yao and Han Chinese [n (\%)]

\begin{tabular}{|c|c|c|c|c|c|c|}
\hline \multirow[t]{2}{*}{ Group } & \multirow[t]{2}{*}{$\mathrm{n}$} & \multicolumn{3}{|c|}{ Genotype } & \multicolumn{2}{|c|}{ Allele } \\
\hline & & $T T$ & $\mathrm{TC}$ & $\mathrm{CC}$ & $T$ & C \\
\hline Bai Ku Yao & 609 & 369 (60.59) & 206 (33.83) & $34(5.53)$ & $944(77.50)$ & $274(22.50)$ \\
\hline Han Chinese & 573 & 299 (52.18) & $232(40.50)$ & $42(7.32)$ & $830(72.43)$ & $316(27.57)$ \\
\hline$\chi^{2}$ & - & & 8.632 & & & \\
\hline$P$ & - & & 0.013 & & & \\
\hline \multicolumn{7}{|l|}{ Bai Ku Yao } \\
\hline Male & 288 & $183(63.54)$ & 93 (32.30) & $12(4.16)$ & 459 (79.69) & $117(20.31)$ \\
\hline Female & 321 & $186(57.95)$ & $113(35.20)$ & $22(6.85)$ & $486(75.47)$ & $158(24.53)$ \\
\hline$\chi^{2}$ & - & & 3.128 & & & \\
\hline$P$ & - & & 0.209 & & & \\
\hline \multicolumn{7}{|l|}{ Han Chinese } \\
\hline Male & 260 & $146(56.15)$ & 97 (37.31) & $17(6.54)$ & $392(74.81)$ & $132(25.19)$ \\
\hline Female & 313 & 153 (48.88) & $135(43.13)$ & $25(7.99)$ & $441(70.45)$ & $185(29.55)$ \\
\hline$\chi^{2}$ & - & & 3.036 & & & \\
\hline$P$ & - & & 0.219 & & & \\
\hline
\end{tabular}

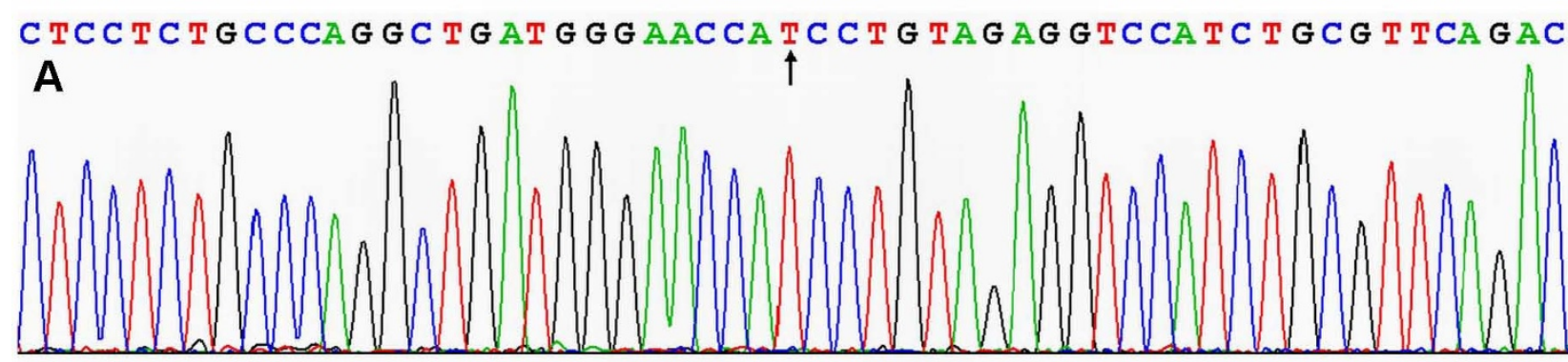

CTC T T T G C CA G T T AT G GAAC CA T C T G TAGAG GT CCAT T GC T TCA GAC

B $\uparrow$

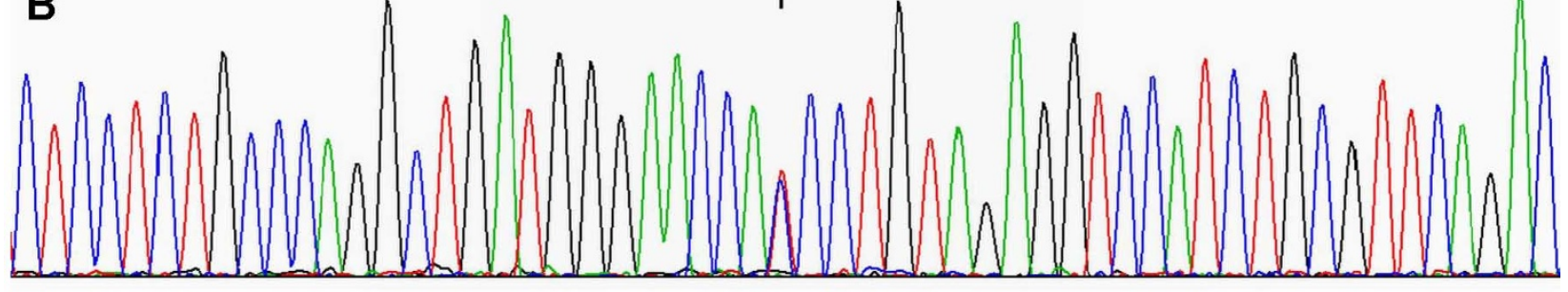

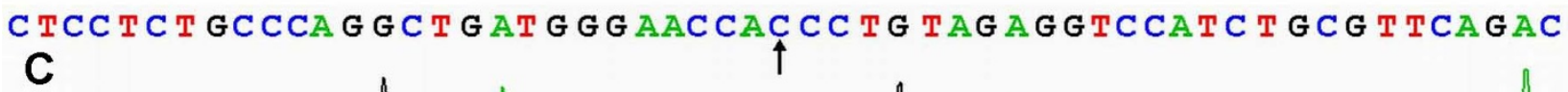

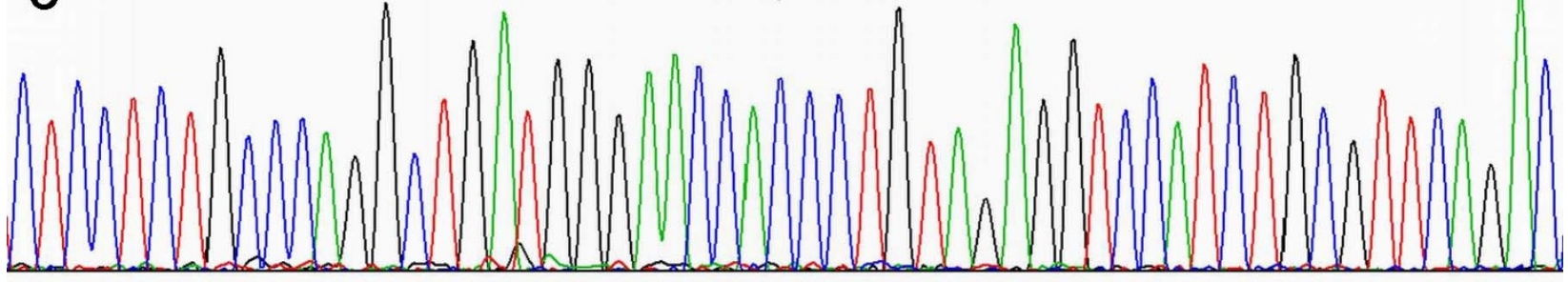

Figure 3 A part of the nucleotide sequence of PPARD +294T > C polymorphism. (A) TT genotype; (B) TC genotype; (C) CC genotype. 
Table 3 Genotypic frequencies of the PPARD +294T > C polymorphism and serum lipid levels between the Bai Ku Yao and Han populations

\begin{tabular}{|c|c|c|c|c|c|c|c|c|}
\hline Genotype & $\mathrm{n}$ & $\begin{array}{l}\mathrm{TC} \\
(\mathrm{mmol} / \mathrm{L})\end{array}$ & $\begin{array}{l}\text { TG } \\
(\mathrm{mmol} / \mathrm{L})\end{array}$ & $\begin{array}{l}\text { HDL-C } \\
(\mathrm{mmol} / \mathrm{L})\end{array}$ & $\begin{array}{l}\text { LDL-C } \\
\text { (mmol/L) }\end{array}$ & $\begin{array}{l}\text { ApoAI } \\
(\mathrm{g} / \mathrm{L})\end{array}$ & $\begin{array}{l}\text { ApoB } \\
\text { (g/L) }\end{array}$ & $\begin{array}{l}\text { ApoAl/ } \\
\text { (g/L) }\end{array}$ \\
\hline \multicolumn{9}{|l|}{ Bai Ku Yao } \\
\hline$\pi$ & 369 & $4.35 \pm 0.97$ & $1.00(0.66)$ & $1.67 \pm 0.42$ & $2.59 \pm 0.81$ & $1.31 \pm 0.32$ & $0.84 \pm 0.22$ & $1.69 \pm 0.73$ \\
\hline $\mathrm{TC}$ & 206 & $4.29 \pm 0.79$ & $0.98(0.63)$ & $1.69 \pm 0.39$ & $2.50 \pm 0.68$ & $1.32 \pm 0.28$ & $0.82 \pm 0.24$ & $1.74 \pm 0.69$ \\
\hline $\mathrm{CC}$ & 34 & $4.63 \pm 0.96$ & $1.92(0.79)$ & $1.72 \pm 0.51$ & $2.79 \pm 0.83$ & $1.36 \pm 0.38$ & $0.89 \pm 0.25$ & $1.68 \pm 0.85$ \\
\hline$F$ & - & 1.951 & 0.102 & 0.339 & 2.454 & 0.286 & 1.658 & 0.376 \\
\hline P & - & 0.143 & 0.950 & 0.713 & 0.087 & 0.751 & 0.191 & 0.687 \\
\hline$\pi$ & 369 & $4.35 \pm 0.97$ & $1.00(0.66)$ & $1.67 \pm 0.42$ & $2.59 \pm 0.81$ & $1.31 \pm 0.32$ & $0.84 \pm 0.22$ & $1.69 \pm 0.73$ \\
\hline TC/CC & 240 & $4.34 \pm 0.82$ & $0.97(0.73)$ & $1.69 \pm 0.41$ & $2.53 \pm 0.71$ & $1.32 \pm 0.30$ & $0.83 \pm 0.24$ & $1.74 \pm 0.72$ \\
\hline$F$ & - & 0.021 & 0.319 & 0.566 & 0.604 & 0.082 & 0.172 & 0.495 \\
\hline P & - & 0.884 & 0.749 & 0.452 & 0.437 & 0.775 & 0.679 & 0.482 \\
\hline \multicolumn{9}{|l|}{ Male } \\
\hline$\pi$ & 183 & $4.35 \pm 1.14$ & $1.03(0.74)$ & $1.69 \pm 0.48$ & $2.54 \pm 0.96$ & $1.35 \pm 0.37$ & $0.81 \pm 0.23$ & $1.83 \pm 0.91$ \\
\hline TC & 93 & $4.38 \pm 0.89$ & $1.21(1.01)$ & $1.73 \pm 0.46$ & $2.48 \pm 0.79$ & $1.38 \pm 0.33$ & $0.82 \pm 0.23$ & $1.84 \pm 0.84$ \\
\hline $\mathrm{CC}$ & 12 & $4.73 \pm 1.07$ & $1.53(1.15)$ & $1.84 \pm 0.50$ & $2.65 \pm 1.01$ & $1.52 \pm 0.41$ & $0.82 \pm 0.24$ & $2.16 \pm 1.20$ \\
\hline$F$ & - & 0.758 & 1.263 & 0.753 & 0.220 & 1.286 & 0.073 & 0.740 \\
\hline$P$ & - & 0.470 & 0.532 & 0.472 & 0.802 & 0.278 & 0.930 & 0.478 \\
\hline$\pi$ & 183 & $4.35 \pm 1.14$ & $1.03(0.74)$ & $1.69 \pm 0.48$ & $2.54 \pm 0.96$ & $1.35 \pm 0.37$ & $0.81 \pm 0.23$ & $1.83 \pm 0.91$ \\
\hline $\mathrm{TC} / \mathrm{CC}$ & 105 & $4.41 \pm 0.91$ & $1.23(1.08)$ & $1.74 \pm 0.46$ & $2.50 \pm 0.82$ & $1.39 \pm 0.34$ & $0.82 \pm 0.24$ & $1.87 \pm 0.89$ \\
\hline$F$ & - & 0.311 & 0.850 & 0.864 & 0.091 & 0.821 & 0.146 & 0.166 \\
\hline P & - & 0.578 & 0.395 & 0.353 & 0.763 & 0.366 & 0.703 & 0.684 \\
\hline \multicolumn{9}{|l|}{ Female } \\
\hline$\pi$ & 186 & $4.36 \pm 0.79$ & $0.94(0.51)$ & $1.66 \pm 0.35$ & $2.64 \pm 0.63$ & $1.28 \pm 0.26$ & $0.86 \pm 0.20$ & $1.55 \pm 0.46$ \\
\hline TC & 113 & $4.23 \pm 0.69$ & $0.92(0.56)$ & $1.67 \pm 0.32$ & $2.50 \pm 0.57$ & $1.27 \pm 0.22$ & $0.82 \pm 0.24$ & $1.66 \pm 0.53$ \\
\hline$C C$ & 22 & $4.57 \pm 0.92$ & $0.81(0.45)$ & $1.65 \pm 0.52$ & $2.87 \pm 0.74$ & $1.27 \pm 0.34$ & $0.93 \pm 0.21$ & $1.41 \pm 0.44$ \\
\hline$F$ & - & 2.265 & 0.697 & 0.031 & 3.759 & 0.064 & 3.264 & 3.280 \\
\hline P & - & 0.106 & 0.706 & 0.969 & 0.024 & 0.938 & 0.040 & 0.039 \\
\hline$\pi$ & 186 & $4.36 \pm 0.79$ & $0.94(0.51)$ & $1.66 \pm 0.35$ & $2.64 \pm 0.63$ & $1.28 \pm 0.26$ & $0.86 \pm 0.20$ & $1.55 \pm 0.46$ \\
\hline $\mathrm{TC} / \mathrm{CC}$ & 135 & $4.28 \pm 0.74$ & $0.91(0.54)$ & $1.67 \pm 0.36$ & $2.57 \pm 0.61$ & $1.27 \pm 0.24$ & $0.84 \pm 0.24$ & $1.62 \pm 0.52$ \\
\hline$F$ & - & 0.795 & 0.799 & 0.030 & 1.086 & 0.129 & 1.289 & 1.565 \\
\hline P & - & 0.373 & 0.425 & 0.862 & 0.298 & 0.720 & 0.257 & 0.212 \\
\hline \multicolumn{9}{|l|}{ Han Chinese } \\
\hline$\pi$ & 299 & $4.65 \pm 0.91$ & $0.99(0.39)$ & $1.92 \pm 0.48$ & $2.56 \pm 0.67$ & $1.40 \pm 0.24$ & $0.88 \pm 0.20$ & $1.66 \pm 0.43$ \\
\hline $\mathrm{TC}$ & 232 & $4.87 \pm 1.14$ & $1.02(0.80)$ & $1.93 \pm 0.51$ & $2.64 \pm 0.81$ & $1.42 \pm 0.25$ & $0.94 \pm 0.23$ & $1.61 \pm 0.46$ \\
\hline$C C$ & 42 & $4.90 \pm 1.19$ & $1.18(0.68)$ & $1.91 \pm 0.50$ & $2.78 \pm 1.01$ & $1.42 \pm 0.22$ & $0.95 \pm 0.25$ & $1.67 \pm 0.94$ \\
\hline$F$ & - & 3.194 & 2.428 & 0.041 & 1.964 & 0.449 & 4.601 & 0.742 \\
\hline P & - & 0.042 & 0.297 & 0.959 & 0.141 & 0.639 & 0.010 & 0.477 \\
\hline$\pi$ & 299 & $4.65 \pm 0.91$ & $0.99(0.39)$ & $1.92 \pm 0.48$ & $2.56 \pm 0.67$ & $1.40 \pm 0.24$ & $0.88 \pm 0.20$ & $1.66 \pm 0.43$ \\
\hline $\mathrm{TC} / \mathrm{CC}$ & 274 & $4.87 \pm 1.14$ & $1.04(0.77)$ & $1.93 \pm 0.51$ & $2.66 \pm 0.84$ & $1.42 \pm 0.25$ & $0.94 \pm 0.24$ & $1.62 \pm 0.56$ \\
\hline$F$ & - & 6.354 & 1.137 & 0.048 & 2.699 & 0.899 & 9.048 & 0.985 \\
\hline P & - & 0.012 & 0.255 & 0.827 & 0.101 & 0.344 & 0.003 & 0.321 \\
\hline \multicolumn{9}{|l|}{ Male } \\
\hline$\pi$ & 146 & $4.59 \pm 0.96$ & $1.01(0.63)$ & $1.87 \pm 0.53$ & $2.51 \pm 0.64$ & $1.39 \pm 0.28$ & $0.88 \pm 0.19$ & $1.63 \pm 0.39$ \\
\hline TC & 97 & $5.01 \pm 1.34$ & 1.14(1.08) & $1.85 \pm 0.58$ & $2.66 \pm 0.91$ & $1.38 \pm 0.27$ & $0.93 \pm 0.24$ & $1.58 \pm 0.47$ \\
\hline$C C$ & 17 & $4.78 \pm 0.76$ & $1.15(1.07)$ & $1.93 \pm 0.60$ & $2.56 \pm 0.43$ & $1.40 \pm 0.07$ & $0.89 \pm 0.24$ & $1.84 \pm 1.33$ \\
\hline$F$ & - & 4.160 & 2.542 & 0.164 & 1.087 & 0.027 & 1.821 & 1.901 \\
\hline P & - & 0.017 & 0.281 & 0.849 & 0.339 & 0.973 & 0.164 & 0.152 \\
\hline$\pi$ & 146 & $4.59 \pm 0.96$ & $1.01(0.63)$ & $1.87 \pm 0.53$ & $2.51 \pm 0.64$ & $1.39 \pm 0.28$ & $0.88 \pm 0.19$ & $1.63 \pm 0.39$ \\
\hline $\mathrm{TC} / \mathrm{CC}$ & 114 & $4.98 \pm 1.27$ & $1.14(1.02)$ & $1.86 \pm 0.55$ & $2.64 \pm 0.85$ & $1.39 \pm 0.26$ & $0.93 \pm 0.24$ & $1.62 \pm 0.67$ \\
\hline F & - & 7.690 & 1.591 & 0.016 & 1.940 & 0.004 & 3.205 & 0.070 \\
\hline$P$ & - & 0.006 & 0.112 & 0.900 & 0.165 & 0.951 & 0.075 & 0.792 \\
\hline
\end{tabular}


Table 3: Genotypic frequencies of the PPARD +294T > C polymorphism and serum lipid levels between the Bai Ku Yao and Han populations (Continued)

$\begin{array}{cllllllll}\text { Female } & & & & & & \\ \text { TT } & 153 & 4.71 \pm 0.85 & 0.97(0.56) & 1.96 \pm 0.44 & 2.60 \pm 0.70 & 1.42 \pm 0.20 & 0.89 \pm 0.21 & 1.68 \pm 0.46 \\ \text { TC } & 135 & 4.76 \pm 0.95 & 0.95(0.68) & 1.98 \pm 0.45 & 2.63 \pm 0.73 & 1.45 \pm 0.23 & 0.94 \pm 0.23 & 1.63 \pm 0.45 \\ \text { CC } & 25 & 4.98 \pm 1.43 & 1.19(0.57) & 1.90 \pm 0.44 & 2.93 \pm 1.25 & 1.44 \pm 0.25 & 0.99 \pm 0.26 & 1.54 \pm 0.52 \\ F & - & 0.887 & 2.362 & 0.406 & 2.009 & 0.822 & 3.265 & 1.120 \\ P & - & 0.413 & 0.307 & 0.667 & 0.136 & 0.441 & 0.039 & 0.328 \\ T & 153 & 4.71 \pm 0.85 & 0.97(0.56) & 1.96 \pm 0.44 & 2.60 \pm 0.70 & 1.42 \pm 0.20 & 0.89 \pm 0.21 & 1.68 \pm 0.46 \\ \text { TC/CC } & 160 & 4.73 \pm 1.04 & 0.99(0.65) & 1.97 \pm 0.45 & 2.67 \pm 0.83 & 1.45 \pm 0.23 & 0.94 \pm 0.23 & 1.61 \pm 0.46 \\ F & - & 0.584 & 0.196 & 0.046 & 0.757 & 1.555 & 5.419 & 1.493 \\ P & - & 0.445 & 0.844 & 0.830 & 0.385 & 0.213 & 0.021 & 0.223\end{array}$

TC, total cholesterol; TG, triglycerides; HDL-C, high-density lipoprotein cholesterol; LDL-C, low-density lipoprotein cholesterol; ApoAl, apolipoprotein Al; ApoB, apolipoprotein B; ApoAl/ApoB, the ratio of apolipoprotein Al to apolipoprotein B. The value of TG was presented as median (interquartile range). The difference among the genotypes was determined by the Kruskal-Wallis test or the Wilcoxon-Mann-Whitney test.

difference in the serum levels of TG, LDL-C and the ratio of ApoAI to ApoB between the two ethnic groups. As aforementioned, dyslipidemia is a multifactorial origin, including hereditary and acquired risk factors and their interactions $[11,12]$. Bai Ku Yao is a special and isolated subgroup of the Yao minority in China. They reside in two villages, Lihu and Baxu, Nandan County. Both Lihu and Baxu villages are typical infertile mountain region, usually it was called 30 percent soil with 70 percent rock. Thus, their income mostly comes from planting corn and paddy. Strict intra-ethnic marriages have been performed in this ethnic subgroup from time immemorial. Therefore, we believe that the variation of some lipid metabolism-related genes in this population may be different from those in Han Chinese.

The genotypic and allelic distribution of PPARD $+294 \mathrm{~T}>$ C polymorphism was different in diverse populations. Several previous studies have showed that the frequency of the rare allele (PPARD +294C) was significantly higher in Russian endurance-oriented athletes than in controls $(18.3 \%$ vs. $12.1 \%, P<0.0001)$ [42], in Tunisian CAD patients than in healthy volunteers (32.0\% vs. $18.9 \%, P=0.001$ ) [34], and in Chinese CAD patients than in normal controls $(30.8 \%$ vs. $19.5 \%, P<$ 0.05) [35]. Some studies, however, showed that there was no difference in its frequency between the patients with diabetes mellitus type 2 and the non-diabetic controls $(18.7 \%$ versus $19.2 \%, P>0.999)$ [37], or among the patients with metabolic syndrome, essential hypertension and diabetes mellitus type 2 [30]. In the present study, we showed that the frequency of PPARD +294C allele was lower in Bai Ku Yao (22.50\%) than in Han Chinese (27.57\%). The frequency of TC and CC genotypes was also lower in Bai Ku Yao than in Han. However, the frequency of PPARD $+294 \mathrm{C}$ allele was higher in both ethnic groups than in 543 healthy 50 -year-oldmen $(15.6 \%)$ from the northern part of the greater Stockholm area [28], in normal controls (19.5\%) from
Chinese Anhui Province [35], in healthy Tunisian population (18.9\%) [34], and in non-diabetic Germany controls (19.2\%) [37]; but it was lower than in Tunisian CAD patients (32.0\%) [34] and Chinese CAD patients (30.8\%) [35]. These results indicate that the prevalence of the C allele variants of PPARD $+294 \mathrm{~T}>\mathrm{C}$ polymorphism may have an ethnic specificity.

The association of PPARD $+294 \mathrm{~T}>\mathrm{C}$ polymorphism and plasma or serum lipid levels in humans has been evaluated in several previous studies. However, the findings are inconsistent. Skogsberg et al. [28] demonstrated that this SNP was implicated in cholesterol metabolism in Swedish men. Homozygotes for the rare $\mathrm{C}$ allele had a higher plasma LDL-C concentration than homozygotes for the common $\mathrm{T}$ allele, which was verified in an independent cohort consisting of 282 healthy men, while there were no associations with the HDL-C levels. Interestingly, the same group of investigators showed in another study in Scottish men that the SNP did not influence LDL-C concentrations but was associated with lower HDL-C levels. Individuals carrying the rare $\mathrm{C}$ allele had a significantly lower HDL-C concentration than subjects homozygous for the common $\mathrm{T}$ allele [29]. Moreover, Aberle et al. [31] showed a highly significant association between the rare $\mathrm{C}$ allele and lower plasma HDL-C concentrations in dyslipidemic female subjects. The effect remained significant after correcting for multiparametric testing according to Bonferoni and was seen only in subjects with a BMI below the median. In addition, several recent reports have also uniformly showed that the PPARD $+294 \mathrm{~T}>\mathrm{C}$ polymorphism was associated with some serum lipid phenotypes. For example, metabolic syndrome patients with CC genotype had significantly higher TC and LDL-C levels than those with TT and TC genotypes [30]. Among subjects with and without type 2 diabetes, the PPARD $+294 \mathrm{~T}>\mathrm{C}$ polymorphism was associated with HDL-C and was dependent on sex [32]. The risk variant of PPARD 
Table 4 Correlative factors for serum lipid parameters between Bai Ku Yao and Han Chinese

\begin{tabular}{|c|c|c|c|c|c|c|}
\hline Lipid parameter & Risk factor & Unstandardized coefficient & Std. error & Standardized coefficient & $t$ & $P$ \\
\hline \multicolumn{7}{|l|}{ Yao plus Han } \\
\hline \multirow[t]{5}{*}{$\mathrm{TC}$} & Body mass index & 0.065 & 0.010 & 0.177 & 6.332 & 0.000 \\
\hline & Ethnic group & 0.373 & 0.055 & 0.187 & 6.810 & 0.000 \\
\hline & Age & 0.009 & 0.002 & 0.140 & 4.926 & 0.000 \\
\hline & Diastolic blood pressure & 0.009 & 0.003 & 0.094 & 3.248 & 0.001 \\
\hline & Genotype & 0.087 & 0.045 & 0.054 & 1.963 & 0.050 \\
\hline \multirow[t]{4}{*}{ TG } & Body mass index & 0.097 & 0.014 & 0.195 & 6.963 & 0.000 \\
\hline & Alcohol consumption & 0.174 & 0.042 & 0.131 & 4.122 & 0.000 \\
\hline & Sex & -0.257 & 0.087 & -0.094 & -2.967 & 0.003 \\
\hline & Genotype & 0.123 & 0.062 & 0.056 & 1.980 & 0.048 \\
\hline \multirow[t]{5}{*}{$\mathrm{HDL}-\mathrm{C}$} & Ethnic group & 0.250 & 0.025 & 0.266 & 9.840 & 0.000 \\
\hline & Age & 0.006 & 0.001 & 0.191 & 6.979 & 0.000 \\
\hline & Alcohol consumption & 0.086 & 0.014 & 0.187 & 6.035 & 0.000 \\
\hline & Sex & 0.111 & 0.029 & 0.117 & 3.846 & 0.000 \\
\hline & Body mass index & -0.017 & 0.005 & -0.102 & -3.763 & 0.000 \\
\hline \multirow[t]{3}{*}{ LDL-C } & Body mass index & 0.054 & 0.008 & 0.194 & 6.870 & 0.000 \\
\hline & Age & 0.007 & 0.001 & 0.135 & 4.724 & 0.000 \\
\hline & Alcohol consumption & -0.087 & 0.021 & -0.116 & -4.055 & 0.000 \\
\hline \multirow[t]{4}{*}{ ApoAl } & Alcohol consumption & 0.067 & 0.009 & 0.240 & 7.605 & 0.000 \\
\hline & Ethnic group & 0.101 & 0.016 & 0.177 & 6.432 & 0.000 \\
\hline & Age & 0.003 & 0.001 & 0.165 & 5.903 & 0.000 \\
\hline & Sex & 0.040 & 0.018 & 0.070 & 2.235 & 0.026 \\
\hline \multirow[t]{6}{*}{ ApoB } & Body mass index & 0.017 & 0.002 & 0.200 & 7.125 & 0.000 \\
\hline & Age & 0.003 & 0.000 & 0.191 & 6.656 & 0.000 \\
\hline & Ethnic group & 0.066 & 0.013 & 0.145 & 5.284 & 0.000 \\
\hline & Alcohol consumption & -0.019 & 0.006 & -0.087 & -3.078 & 0.002 \\
\hline & Diastolic blood pressure & 0.001 & 0.001 & 0.068 & 2.310 & 0.021 \\
\hline & Genotype & 0.023 & 0.010 & 0.065 & 2.234 & 0.026 \\
\hline \multirow[t]{3}{*}{ ApoAl/ApoB } & Alcohol consumption & 0.133 & 0.017 & 0.218 & 7.608 & 0.000 \\
\hline & Body mass index & -0.034 & 0.006 & -0.148 & -5.250 & 0.000 \\
\hline & Age & -0.002 & 0.001 & -0.062 & -2.169 & 0.030 \\
\hline \multicolumn{7}{|l|}{ Bai Ku Yao } \\
\hline \multirow[t]{2}{*}{$\mathrm{TC}$} & Body mass index & 0.072 & 0.015 & 0.189 & 4.776 & 0.000 \\
\hline & Age & 0.008 & 0.002 & 0.142 & 3.598 & 0.000 \\
\hline \multirow[t]{3}{*}{ TG } & Alcohol consumption & 0.094 & 0.040 & 0.110 & 2.329 & 0.020 \\
\hline & Body mass index & 0.054 & 0.015 & 0.139 & 3.503 & 0.000 \\
\hline & Sex & -0.238 & 0.087 & -0.128 & -2.735 & 0.006 \\
\hline \multirow[t]{2}{*}{$\mathrm{HDL}-\mathrm{C}$} & Alcohol consumption & 0.069 & 0.015 & 0.180 & 4.547 & 0.000 \\
\hline & Age & 0.005 & 0.001 & 0.171 & 4.335 & 0.000 \\
\hline \multirow[t]{3}{*}{ LDL-C } & Body mass index & 0.063 & 0.013 & 0.196 & 4.954 & 0.000 \\
\hline & Age & 0.006 & 0.002 & 0.129 & 3.245 & 0.001 \\
\hline & Cigarette smoking & -0.062 & 0.025 & -0.097 & -2.446 & 0.015 \\
\hline \multirow[t]{2}{*}{ ApoAl } & Alcohol consumption & 0.082 & 0.011 & 0.283 & 7.324 & 0.000 \\
\hline & Age & 0.003 & 0.001 & 0.136 & 3.523 & 0.000 \\
\hline \multirow[t]{3}{*}{ ApoB } & Body mass index & 0.020 & 0.004 & 0.208 & 5.286 & 0.000 \\
\hline & Age & 0.002 & 0.001 & 0.167 & 4.209 & 0.000 \\
\hline & Alcohol consumption & -0.023 & 0.008 & -0.109 & -2.753 & 0.006 \\
\hline ApoAl/ApoB & Alcohol consumption & 0.197 & 0.026 & 0.295 & 7.605 & 0.000 \\
\hline \multicolumn{7}{|l|}{ Han Chinese } \\
\hline \multirow[t]{2}{*}{$\mathrm{TC}$} & Diastolic blood pressure & 0.013 & 0.004 & 0.135 & 3.235 & 0.001 \\
\hline & Body mass index & 0.060 & 0.014 & 0.176 & 4.350 & 0.000 \\
\hline
\end{tabular}


Table 4: Correlative factors for serum lipid parameters between Bai Ku Yao and Han Chinese (Continued)

\begin{tabular}{|c|c|c|c|c|c|c|}
\hline & Age & 0.010 & 0.003 & 0.163 & 3.964 & 0.000 \\
\hline & Genotype & 0.136 & 0.065 & 0.083 & 2.081 & 0.038 \\
\hline \multirow[t]{2}{*}{ TG } & Body mass index & 0.127 & 0.022 & 0.226 & 5.648 & 0.000 \\
\hline & Alcohol consumption & 0.353 & 0.071 & 0.198 & 4.954 & 0.000 \\
\hline \multirow[t]{4}{*}{$\mathrm{HDL}-\mathrm{C}$} & Age & 0.008 & 0.001 & 0.242 & 5.975 & 0.000 \\
\hline & Body mass index & -0.023 & 0.006 & -0.140 & -3.557 & 0.000 \\
\hline & Sex & 0.158 & 0.042 & 0.160 & 3.760 & 0.000 \\
\hline & Alcohol consumption & 0.072 & 0.022 & 0.140 & 3.211 & 0.001 \\
\hline \multirow[t]{3}{*}{ LDL-C } & Body mass index & 0.046 & 0.010 & 0.185 & 4.584 & 0.000 \\
\hline & Alcohol consumption & -0.119 & 0.033 & -0.150 & -3.610 & 0.000 \\
\hline & Age & 0.007 & 0.002 & 0.148 & 3.575 & 0.000 \\
\hline \multirow[t]{3}{*}{ ApoAl } & Age & 0.004 & 0.001 & 0.232 & 5.694 & 0.000 \\
\hline & Sex & 0.082 & 0.021 & 0.168 & 3.917 & 0.000 \\
\hline & Alcohol consumption & 0.039 & 0.011 & 0.155 & 3.527 & 0.000 \\
\hline \multirow[t]{3}{*}{ ApoB } & Age & 0.003 & 0.001 & 0.239 & 6.076 & 0.000 \\
\hline & Body mass index & 0.016 & 0.003 & 0.218 & 5.540 & 0.000 \\
\hline & Genotype & 0.035 & 0.014 & 0.098 & 2.498 & 0.013 \\
\hline ApoAl/ApoB & Body mass index & -0.032 & 0.007 & -0.197 & -4.794 & 0.000 \\
\hline
\end{tabular}

TC, total cholesterol; TG, triglyceride; HDL-C, high-density lipoprotein cholesterol; LDL-C, low-density lipoprotein cholesterol; ApoAl, apolipoprotein Al; ApoB, apolipoprotein B.

+294T > C marker was associated with higher LDL-C and increased serum TC [33]. However, Gouni-Berthold et al. [37] found that the presence of the $C$ allele had no effect on TG, HDL-C, and LDL-C levels, both in diabetic and non-diabetic German controls, or both in men and in women. The same result was found by JguirimSouissi et al. [34] both in CAD patients and healthy controls. In the present study, we showed that the levels of LDL-C, ApoB and the ratio of ApoAI to ApoB in Bai $\mathrm{Ku}$ Yao were significant difference among the three genotypes in females but not in males. The subjects with $C C$ genotype in females had higher serum LDL-C and ApoB levels and lower the ratio of ApoAI to ApoB than the subjects with TT and TC genotypes. In contrast, the levels of TC and ApoB in the total Han population were significant difference among the three genotypes. The $\mathrm{C}$ allele carriers had higher serum TC and ApoB levels as compared with the $C$ allele noncarriers. When serum lipid levels were analyzed according to sex, the difference in serum TC levels in Han Chinese was significant in males but not in females, whereas the difference in serum ApoB levels was significant in females but not in males. Serum TC and ApoB levels were correlated with genotypes in Han but not in Bai Ku Yao. These results suggest that the association of PPARD $+294 \mathrm{~T}>\mathrm{C}$ polymorphism and serum lipid levels is different between the Bai Ku Yao and Han populations. The discrepancy between the two ethnic groups might partly result from different PPARD $+294 \mathrm{~T}>\mathrm{C}$ polymorphism or PPARD gene-enviromental interactions.
In the present study, we also found that serum lipid parameters were associated with age, sex, alcohol consumption, cigarette smoking, BMI, and blood pressure. These results suggest that the environmental factors also play important roles in dyslipidemia in our populations $[6,7]$. The dietary patterns and lifestyle between the two ethnic groups were different. The staple food was corn and the subsidiary foods were rice, soy, buckwheat, sweet potato, and pumpkin products in Bai Ku Yao. Approximately $90 \%$ of the beverages were corn wine and rum. The alcohol content is about $15 \%(\mathrm{v} / \mathrm{v})$. The people of Bai Ku Yao are also accustomed to drink hempseed soup and eat hempseed products. In contrast, rice was the staple food and corn, broomcorn, potato, and taro products were the subsidiary foods in Han. About $90 \%$ of the beverage was rice wine. The content of alcohol is about $30 \%(\mathrm{v} / \mathrm{v})$. The staple and subsidiary foods are more favorable for serum lipid profiles in Bai $\mathrm{Ku}$ Yao than in Han. Corn contains abundant dietary fiber and plant protein [43]. Consumption of dietary fiber can decrease serum lipid levels $[44,45]$. A dietary supplement of water-soluble fibers (guar gum, pectin) and mostly non-water-soluble fibers (soy fiber, pea fiber, corn bran) in subjects with mild to moderate hypercholesterolemia (LDL-C, 3.37-4.92 mmol/L) had significant blood cholesterol-lowering effects. The mean decreases during the 15-week period for LDL-C, TC, and LDL-C/ HDL-C ratio were greater $(P<0.001)$ in the fiber group. The mean changes from pre-treatment values in LDL-C, $\mathrm{TC}$, and LDL-C/HDL-C ratio for subjects in the fiber 
group were $-0.51 \mathrm{mmol} / \mathrm{L}(-12.1 \%),-0.53 \mathrm{mmol} / \mathrm{L}$ $(-8.5 \%)$, and $-0.30(-9.4 \%)$; respectively. But the fiber supplement had no significant effects on HDL-C and TG [45]. Plant protein might promote the transportation and excretion of free cholesterol. Dietary soy protein has well-documented beneficial effects on serum lipid concentrations [46,47]. Soy protein with isoflavones intact was associated with significant decreases in serum TC (by $0.22 \mathrm{mmol} / \mathrm{L}$, or $3.77 \%$ ), LDL-C (by $0.21 \mathrm{mmol} / \mathrm{L}$, or $5.25 \%$ ), and TG (by $0.10 \mathrm{mmol} / \mathrm{L}$, or $7.27 \%$ ) and significant increases in serum HDL-C (by $0.04 \mathrm{mmol} / \mathrm{L}$, or $3.03 \%)$. The reductions in total and LDL-C were larger in men than in women. Initial TC concentrations had a powerful effect on changes in total and HDL-C, especially in subjects with hypercholesterolemia. Studies with intakes $>80 \mathrm{mg}$ showed better effects on the lipid profile. The strongest lowering effects of soy protein containing isoflavones on TC, LDL-C, and TG occurred within the short initial period of intervention, whereas improvements in HDL-C were only observed in studies of $>12$ wk duration [47]. Buckwheat protein product has a potent hypocholesterolemic activity $[48,49]$. Plasma TC concentrations in rats fed a cholesterol-free diet with tartary buckwheat sprout powder were significantly lower than in the control rats fed a diet with alpha-cornstarch. The cholesterol-lowering function of tartary buckwheat sprout powder may be achieved by enhancing fecal bile acid excretion through increased fecal matter excretion or the upregulation of hepatic cholesterol 7alpha-hydroxylase mRNA expression [49]. Ingestion of $4 \mathrm{~g} /$ day caiapo (the extract of the whiteskinned sweet potato Ipomoea batatas) for 6 weeks has been found to reduce plasma TC and LDL-C levels in type 2 diabetic patients previously treated by diet alone [50]. Chang et al. [51] have evaluated the effect of purple sweet potato leaves (PSPLs) consumption on antioxidative status and its modulation of that status in basketball players during training period. The results showed that LDL lag time was significantly longer in the PSPLs group, sugesting that consumption of PSPLs diet for 2 weeks may reduce lipid and DNA oxidation that can modulate the antioxidative status of basketball players during training period. Adaramoye et al. [52] reported that supplemented diets containing 3\% and 6\% telfairia occidentalis (fluted pumpkin) in rats decreased plasma and postmitochondrial supernatant fraction (PMF) cholesterol levels by $20 \%$ and $30 \%$ and by $30 \%$ and $45 \%$, respectively; decreased the cholesterol-induced increase in plasma and PMF LDL-C levels by $24 \%$ and $48 \%$ and by $28 \%$ and $52 \%$, respectively; and decreased plasma and PMF lipid peroxidation by $24 \%$ and $20 \%$ and by $42 \%$ and $21 \%$, respectively. Hempseed contains a high proportion of the polyunsaturated fatty acids (PUFAs) such as linoleic acid, linolenic acid, oleic acid, palmitic acid, and stearic acid, which may have beneficial effects on serum lipid profiles. Hempseedsupplemented diet in animals displayed elevated plasma levels of PUFAs and a prominent enhancement in gamma-linolenic acid levels. When hempseed is added to a cholesterol-enriched diet, cholesterol-induced platelet aggregation returns to control levels [53,54]. This normalization may be partly due to increased levels of plasma gamma-linolenic acid [53]. In addition, several experimental and clinical studies have demonstrated that dietary hempseed or hempseed oil can decrease serum TC, TG and LDL-C levels [55-57], inhibit lipid peroxidation [58], and reduce atherogenic index [59].

\section{Conclusion}

The present study shows that the frequency of PPARD $+294 \mathrm{C}$ allele was lower in Bai Ku Yao than in Han Chinese. The subjects with CC genotype in Bai Ku Yao had higher serum LDL-C and ApoB levels and lower the ratio of ApoAI to ApoB than the subjects with TT and $\mathrm{TC}$ genotypes in females but not in males. The $\mathrm{C}$ allele carriers in Han Chinese had higher serum TC and ApoB levels than the $C$ allele noncarriers. When serum lipid levels were analyzed according to sex, the difference in serum TC levels in Han Chinese was significant in males but not in females, whereas the difference in serum ApoB levels was significant in females but not in males. Serum $\mathrm{TC}$ and $\mathrm{ApoB}$ levels were correlated with genotypes in $\mathrm{Han}$ but not in Bai Ku Yao. These results suggest that the association of PPARD $+294 \mathrm{~T}>\mathrm{C}$ polymorphism and serum lipid levels is different between the Bai Ku Yao and Han populations. The difference in the association of PPARD $+294 \mathrm{~T}>\mathrm{C}$ polymorphism and serum lipid levels between the two ethnic groups might partly result from different PPARD $+294 \mathrm{~T}>$ C polymorphism or PPARD gene-enviromental interactions.

\section{Acknowledgements}

This study was supported by the National Natural Science Foundation of China (No: 30660061)

\section{Author details}

'Department of Cardiology, Institute of Cardiovascular Diseases, the First Affiliated Hospital, Guangxi Medical University, 22 Shuangyong Road, Nanning 530021, Guangxi, People's Republic of China. ${ }^{2}$ Department of Molecular Biology, Medical Scientific Research Center, Guangxi Medical University, 22 Shuangyong Road, Nanning 530021, Guangxi, People's Republic of China.

\section{Authors' contributions}

LM participated in the design, undertook genotyping, and helped to draft the manuscript. RXY conceived the study, participated in the design, carried out the epidemiological survey, collected the samples, and drafted the manuscript. DFW, XLC, QL, XJH, TTY and LHHA collaborated to the genotyping. DZY and WXL carried out the epidemiological survey, collected the samples, and helped to carry out the genotyping. All authors read and approved the final manuscript. 


\section{Competing interests}

The authors declare that they have no competing interests.

Received: 29 November 2010 Accepted: 21 December 2010

Published: 21 December 2010

\section{References}

1. Austin MA, Hokanson JE, Edwards KL: Hypertriglyceridemia as a cardiovascular risk factor. Am J Cardiol 1998, 81:7B-12B.

2. Castelli WP, Anderson K, Wilson PW, Levy D: Lipids and risk of coronary heart disease. The Framingham Study. Ann Epidemiol 1992, 2:23-8.

3. Brunzell JD, Sniderman AD, Albers JJ, Kwiterovich PO Jr: Apoproteins B and A-I and coronary artery disease in humans. Arteriosclerosis 1984, 4:79-83.

4. Holewijn S, den Heijer M, Swinkels DW, Stalenhoef AFH, de Graaf J: Apolipoprotein B, non-HDL cholesterol and LDL cholesterol for identifying individuals at increased cardiovascular risk. J Intern Med 2010, 268:567-77.

5. Sing CF, Stengård JH, Kardia SL: Genes, environment, and cardiovascular disease. Arterioscler Thromb Vasc Biol 2003, 23:1190-6.

6. Ruixing Y, Qiming F, Dezhai Y, Shuquan L, Weixiong L, Shangling P, Hai W, Yongzhong Y, Feng H, Shuming Q: Comparison of demography, diet, lifestyle, and serum lipid levels between the Guangxi Bai Ku Yao and Han populations. J Lipid Res 2007, 48:2673-81.

7. Ruixing Y, Dezhai Y, Shuquan L, Yuming C, Hanjun Y, Qiming F, Shangling $P$, Weixiong $L$, Jing $T$, Yiyang L: Hyperlipidaemia and its risk factors in the Guangxi Bai Ku Yao and Han populations. Public Health Nutr 2009, 12:816-24.

8. Liu WY, Yin RX, Zhang L, Cao XL, Miao L, Wu DF, Aung LH, Hu XJ, Lin WX Yang DZ: Association of the LIPG 584C > T polymorphism and serum lipid levels in the Guangxi Bai Ku Yao and Han populations. Lipids Health Dis 2010, 9:110.

9. Zhang L, Yin RX, Liu WY, Miao L, Wu DF, Aung LH, Hu XJ, Cao XL, Wu JZ, Pan SL: Association of methylenetetrahydrofolate reductase C677T polymorphism and serum lipid levels in the Guangxi Bai Ku Yao and Han populations. Lipids Health Dis 2010, 9:123.

10. Meng $L$, Ruixing $Y$, Yiyang $L$, Xingjiang $L$, Kela $L$, Wanying $L$, Lin $Z$, Weixiong L, Dezhai Y, Shangling P: Association of LIPC -250G > A polymorphism and several environmental factors with serum lipid levels in the Guangxi Bai Ku Yao and Han populations. Lipids Health Dis 2010, 9:28.

11. Ruixing $Y$, Yiyang $L$, Meng $L$, Kela $L$, Xingjiang $L$, Lin $Z$, Wanying $L$, Jinzhen W, Dezhai $Y$, Weixiong L: Interactions of the apolipoprotein C-III $3238 \mathrm{C}>\mathrm{G}$ polymorphism and alcohol consumption on serum triglyceride levels. Lipids Health Dis 2010, 9:86.

12. Zhou $Y$, Yin $R$, Deng $Y, L i Y$, , Wu J: Interactions between alcohol intake and the polymorphism of rs708272 on serum high-density lipoprotein cholesterol levels in the Guangxi Hei Yi Zhuang population. Alcohol 2008, 42:583-91.

13. Heller DA, de Faire U, Pedersen NL, Dahlén G, McClearn GE: Genetic and environmental influences on serum lipid levels in twins. N Engl J Med 1993, 328:1150-6.

14. Steinmetz J, Boerwinkle E, Gueguen R, Visvikis S, Henny J, Siest G: Multivariate genetic analysis of high density lipoprotein particles. Atherosclerosis 1992, 92:219-27.

15. Pérusse L, Rice T, Després JP, Bergeron J. Province MA, Gagnon J, Leon AS, Rao DC, Skinner JS, Wilmore JH, Bouchard C: Familial resemblance of plasma lipids, lipoproteins and postheparin lipoprotein and hepatic lipases in the HERITAGE Family Study. Arterioscler Thromb Vasc Biol 1997, 17:3263-9.

16. Lusis AJ, Mar R, Pajukanta P: Genetics of atherosclerosis. Annu Rev Genomics Hum Genet 2004, 5:189-218,

17. Beekman M, Heijmans BT, Martin NG, Pedersen NL, Whitfield JB, DeFaire U, van Baal GC, Snieder H, Vogler GP, Slagboom PE, Boomsma Dl: Heritabilities of apolipoprotein and lipid levels in three countries. Twin Res 2002, 5:87-97.

18. Reddy JK, Hashimoto T: Peroxisomal beta-oxidation and peroxisome proliferator-activated receptor alpha: an adaptive metabolic system. Annu Rev Nutr 2001, 21:193-230.

19. Spiegelman BM, Flier JS: Adipogenesis and obesity: rounding out the big picture. Cell 1996, 87:377-89.
20. Skogsberg J, Kannisto K, Roshani L, Gagne E, Hamsten A, Larsson C, Ehrenborg E: Characterization of the human peroxisome proliferator activated receptor delta gene and its expression. Int J Mol Med 2000, 6:73-81.

21. Blaschke F, Takata Y, Caglayan E, Law RE, Hsueh WA: Obesity, peroxisome proliferator-activated receptor, and atherosclerosis in type 2 diabetes. Arterioscler Thromb Vasc Biol 2006, 26:28-40.

22. Seedorf $\mathrm{U}$, Aberle J: Emerging roles of PPARdelta in metabolism. Biochim Biophys Acta 2007, 1771:1125-31.

23. Juge-Aubry C, Pernin A, Favez T, Burger AG, Wahli W, Meier CA, Desvergne B: DNA binding properties of peroxisome proliferatoractivated receptor subtypes on various natural peroxisome proliferator response elements. Importance of the $5^{\prime}$-flanking region. J Biol Chem 1997, 272:25252-9

24. Oliver WR Jr, Shenk JL, Snaith MR, Russell CS, Plunket KD, Bodkin NL, Lewis MC, Winegar DA, Sznaidman ML, Lambert MH, Xu HE, Sternbach DD, Kliewer SA, Hansen BC, Willson TM: A selective peroxisome proliferatoractivated receptor delta agonist promotes reverse cholesterol transport. Proc Natl Acad Sci USA 2001, 98:5306-11.

25. Dressel U, Allen TL, Pippal JB, Rohde PR, Lau P, Muscat GE: The peroxisome proliferator-activated receptor beta/delta agonist, GW501516, regulates the expression of genes involved in lipid catabolism and energy uncoupling in skeletal muscle cells. Mol Endocrinol 2003, 17:2477-93.

26. Leibowitz MD, Fiévet C, Hennuyer N, Peinado-Onsurbe J, Duez H, Bergera J, Cullinan CA, Sparrow CP, Baffic J, Berger GD, Santini C, Marquis RW, Tolman RL, Smith RG, Moller DE, Auwerx J: Activation of PPARdelta alters lipid metabolism in db/db mice. FEBS Lett 2000, 473:333-6.

27. Luquet S, Lopez-Soriano J, Holst D, Fredenrich A, Melki J, Rassoulzadegan M, Grimaldi PA: Peroxisome proliferator-activated receptor delta controls muscle development and oxidative capability. FASEB J 2003, 17:2299-301.

28. Skogsberg J, Kannisto K, Cassel TN, Hamsten A, Eriksson P, Ehrenborg E: Evidence that peroxisome proliferator-activated receptor delta influences cholesterol metabolism in men. Arterioscler Thromb Vasc Biol 2003, 23:637-43.

29. Skogsberg J, McMahon AD, Karpe F, Hamsten A, Packard CJ, Ehrenborg E, West of Scotland Coronary Prevention Study: Peroxisome proliferator activated receptor delta genotype in relation to cardiovascular risk factors and risk of coronary heart disease in hypercholesterolaemic men. $J$ Intern Med 2003, 254:597-604.

30. Yan ZC, Shen CY, Zhong J, Wang L, Ni YX, Nie H, Zhu ZM: PPARdelta + 294T/C gene polymorphism related to plasma lipid, obesity and left ventricular hypertrophy in subjects with metabolic syndrome. Zhonghua Xin Xue Guan Bing Za Zhi 2005, 33:529-33.

31. Aberle J, Hopfer I, Beil FU, Seedorf U: Association of the T+294C polymorphism in PPAR delta with low HDL cholesterol and coronary heart disease risk in women. Int J Med Sci 2006, 3:108-11.

32. Burch LR, Donnelly LA, Doney AS, Brady J, Tommasi AM, Whitley AL, Goddard C, Morris AD, Hansen MK, Palmer CN: Peroxisome proliferatoractivated receptor-delta genotype influences metabolic phenotype and may influence lipid response to statin therapy in humans: a genetics of diabetes audit and research Tayside study. J Clin Endocrinol Me 2010.

33. Nikitin AG, Chistiakov DA, Minushkina LO, Zateyshchikov DA, Nosikov W: Association of the CYBA, PPARGC1A, PPARG3, and PPARD gene variants with coronary artery disease and metabolic risk factors of coronary atherosclerosis in a Russian population. Heart Vessels 2010, 25:229-36.

34. Jguirim-Souissi I, Jelassi A, Hrira Y, Najah M, Slimani A, Addad F, Hassine M, Hamda KB, Maatouk F, Rouis M, Slimane MN: +294T/C polymorphism in the PPAR-delta gene is associated with risk of coronary artery disease in normolipidemic Tunisians. Genet Mol Res 2010, 9:1326-33.

35. Wang LF, Tan M, Chang H, Yu H, Shen JJ: Relationship of peroxisome proliferation-activated receptor-delta +294 T/C gene polymorphism with coronary artery disease. Acta Univ Med Anhui 2008, 43:701-5.

36. Holzapfel J, Heun R, Lütjohann D, Jessen F, Maier W, Kölsch H: PPARD haplotype influences cholesterol metabolism but is no risk factor of Alzheimer's disease. Neurosci Lett 2006, 408:57-61.

37. Gouni-Berthold I, Giannakidou E, Faust M, Berthold HK, Krone W: The peroxisome proliferator-activated receptor delta $+294 \mathrm{~T} / \mathrm{C}$ polymorphism in relation to lipoprotein metabolism in patients with diabetes mellitus type 2 and in non-diabetic controls. Atherosclerosis 2005, 183:336-41. 
38. People's Republic of China-United States Cardiovascular and Cardiopulmonary Epidemiology Research Group: An epidemiological study of cardiovascular and cardiopulmonary disease risk factors in four populations in the People's Republic of China. Baseline report from the P.R.C.-U.S.A. Collaborative Study. Circulation 1992, 85:1083-96.

39. Ruixing $Y$, Weixiong $L$, Hanjun $Y$, Dezhai $Y$, Shuquan $L$, Shangling $P$, Qiming F, Jinzhen W, Jianting G, Yaju D: Diet, lifestyle, and blood pressure of the middle-aged and elderly in the Guangxi Bai Ku Yao and Han populations. Am J Hypertens 2008, 21:382-7.

40. Ruixing $Y$, Shangling $P$, Shuquan $L$, Dezhai $Y$, Weixiong L, Qiming F, Yuming C, Yaoheng H, Yijiang Z, Qinchen L: Comparison of hypertension and its risk factors between the Guangxi Bai Ku Yao and Han populations. Blood Press 2008, 17:306-16.

41. Cooperative Meta-analysis Group of China Obesity Task Force: Predictive values of body mass index and waist circumference to risk factors of related diseases in Chinese adult population. Chin J Epidemiol 2002, 23:5-10.

42. Akhmetov II, Astranenkova IV, Rogozkin VA: Association of PPARD gene polymorphism with human physical performance. Mol Biol (Mosk) 2007, 41:852-7.

43. Dong W, Ma X, Zhang D, Yu S: Effect of maize embryo on delaying aging. Food Sci 2002, 23:95-7.

44. Lairon D: Dietary fibres: effects on lipid metabolism and mechanisms of action. Eur J Clin Nutr 1996, 50:125-33.

45. Knopp RH, Superko HR, Davidson M, Insull W, Dujovne CA, Kwiterovich PO, Zavoral JH, Graham K, O'Connor RR, Edelman DA: Long-term blood cholesterol-lowering effects of a dietary fiber supplement. Am J Prev Med 1999, 17:18-23.

46. Weggemans RM, Trautwein EA: Relation between soy-associated isoflavones and LDL and HDL cholesterol concentrations in humans: a meta-analysis. Eur J Clin Nutr 2003, 57:940-6.

47. Zhan S, Ho SC: Meta-analysis of the effects of soy protein containing isoflavones on the lipid profile. Am J Clin Nutr 2005, 81:397-408.

48. Tomotake H, Shimaoka I, Kayashita J, Yokoyama F, Nakajoh M, Kato N: Stronger suppression of plasma cholesterol and enhancement of the fecal excretion of steroids by a buckwheat protein product than by a soy protein isolate in rats fed on a cholesterol-free diet. Biosci Biotechnol Biochem 2001, 65:1412-4

49. Kuwabara T, Han KH, Hashimoto N, Yamauchi H, Shimada K, Sekikawa M, Fukushima M: Tartary buckwheat sprout powder lowers plasma cholesterol level in rats. J Nutr Sci Vitaminol (Tokyo) 2007, 53:501-7.

50. Ludvik BH, Mahdjoobian K, Waldhaeusl W, Hofer A, Prager R, KautzkyWiller A, Pacini G: The effect of Ipomoea batatas (Caiapo) on glucose metabolism and serum cholesterol in patients with type 2 diabetes: a randomized study. Diabetes Care 2002, 25:239-40.

51. Chang WH, Chen CM, Hu SP, Kan NW, Chiu CC, Liu JF: Effect of purple sweet potato leaf consumption on the modulation of the antioxidative status in basketball players during training. Asia Pac J Clin Nutr 2007, 16:455-61.

52. Adaramoye OA, Achem J, Akintayo OO, Fafunso MA: Hypolipidemic effect of Telfairia occidentalis (fluted pumpkin) in rats fed a cholesterol-rich diet. J Med Food 2007, 10:330-6.

53. Prociuk MA, Edel AL, Richard MN, Gavel NT, Ander BP, Dupasquier CM, Pierce GN: Cholesterol-induced stimulation of platelet aggregation is prevented by a hempseed-enriched diet. Can J Physiol Pharmacol 2008, 86:153-9.

54. Richard MN, Ganguly R, Steigerwald SN, Al-Khalifa A, Pierce GN: Dietary hempseed reduces platelet aggregation. J Thromb Haemost 2007, 5:424-5.

55. Cen L, Qin W, Ye Y: Effect of Canabis Sativa $L$ on serum cholesterol level in rats. J Guangxi Med Univ 1984, 1:20-2.

56. Qin W, Cen L, Ye Y: The effect of some foods on serum cholesterol level in rats. Acta Nutrimenta Sinica 1986, 8:136-40.

57. Schwab US, Callaway J, Erkkila AT, Gynther J, Uusitupa MI, Jarvinen T: Effects of hempseed and flaxseed oils on the profile of serum lipids, serum total and lipoprotein lipid concentrations and haemostatic factors. Eur J Nutr 2006, 45:470-7.

58. Ren HY, Sun HG, Ma JZ, Zhang Y, Yi CR, Wu MX, Liu WL, Li GL: Experimental study on the effects of hemp fruit oil on serun lipid levels and lipid peroxidation. Chin J Tradit Med Sci Technol 1997, 4:200.
59. Ren HY, Sun HG, Zhang Y, Yi CR, Wu MX, Li GL, Liu WL: Lipid-lowering and antiatherosclerotic effects of hemp fruit oil in partridges. Henan Tradit Chin Med 1998, 18:294-5.

doi:10.1186/1476-511X-9-145

Cite this article as: Miao et al:: Peroxisome proliferator-activated receptor delta $+294 \mathrm{~T}>\mathrm{C}$ polymorphism and serum lipid levels in the Guangxi Bai Ku Yao and Han populations. Lipids in Health and Disease 2010 9:145.

\section{Submit your next manuscript to BioMed Central and take full advantage of:}

- Convenient online submission

- Thorough peer review

- No space constraints or color figure charges

- Immediate publication on acceptance

- Inclusion in PubMed, CAS, Scopus and Google Scholar

- Research which is freely available for redistribution

Submit your manuscript at www.biomedcentral.com/submit
C) Biomed Central 